\title{
Effects of flow events and nutrient addition on stream periphyton and macroinvertebrates: an experimental study using flumes
}

\author{
Knut Andreas E. Bækkelie ${ }^{1}$, Susanne C. Schneider, ${ }^{2, *}$, Camilla H.C. Hagman ${ }^{2}$ and Zlatko Petrin ${ }^{1}$ \\ ${ }^{1}$ Norwegian Institute for Nature Research, P.O. Box 5685 Torgard, 7485 Trondheim, Norway \\ ${ }^{2}$ Norwegian Institute for Water Research, Gaustadalleen 21, 0349 Oslo, Norway
}

\begin{abstract}
We used flume experiments to study the effects of a temporary increase in stream flow on macroinvertebrates, leaf litter breakdown and soft-bodied benthic algae; both as a single stressor and eventually in combination with an increase in nutrient supply. In order to understand how well the flumes reflected the nearby stream ecosystem, we compared species composition of macroinvertebrates and benthic algae between the flumes and the nearby stream from which the flumes were supplied with water. As single stressors, nutrient addition and an increased flow velocity from 1.3 to $2.8 \mathrm{~cm} \mathrm{~s}^{-1}$ lead to an increase in the biomass of benthic algae, likely reflecting an improved transfer of nutrients into algal patches. However, the combined effect of flow and nutrient addition was smaller than the sum of both individual effects, likely because an increased biomass also was more susceptible to scouring. We found differences in macroinvertebrate and benthic algal taxon identity and abundance between stream and flumes. Since biodiversity is assumed to stabilize ecological functioning in response to disturbances and variation, we conclude that care should be taken in applying results from small scale experiments to stream ecosystems.
\end{abstract}

Keywords: river flow / eutrophication / periphyton / macroinvertebrates / flume experiment

Résumé - Effets des épisodes d'écoulement et de l'adjonction de nutriments sur le périphyton et les macroinvertébrés des cours d'eau : une étude expérimentale utilisant des canaux. Nous avons utilisé des expériences en canaux pour étudier les effets d'une augmentation temporaire du débit sur les macroinvertébrés, la dégradation de la litière foliaire et les algues benthiques à corps mou, à la fois comme stresseur unique et éventuellement en combinaison avec une augmentation de l'apport en éléments nutritifs. Afin de comprendre dans quelle mesure les canaux reflétaient bien l'écosystème du cours d'eau voisin, nous avons comparé la composition spécifique des macroinvertébrés et des algues benthiques entre les canaux et le cours d'eau voisin qui alimentait les canaux en eau. En tant que stresseurs uniques, l'ajout de nutriments et une vitesse d'écoulement accrue de 1,3 à $2,8 \mathrm{~cm} \mathrm{~s}^{-1}$ entraînent une augmentation de la biomasse des algues benthiques, ce qui reflète probablement un meilleur transfert des nutriments dans le périphyton algal. Toutefois, l'effet combiné du débit et de l'adjonction de nutriments était plus faible que la somme des deux effets individuels, probablement parce qu'une biomasse accrue était aussi plus susceptible de se décoller. Nous avons trouvé des différences dans l'identité et l'abondance des taxons de macroinvertébrés et des taxons d'algues benthiques entre le cours d'eau et les canaux. Puisque la biodiversité est supposée stabiliser le fonctionnement écologique en réponse aux perturbations et aux variations, nous concluons qu'il faut faire preuve de prudence dans l'application aux écosystèmes des cours d'eau des résultats d'expériences à petite échelle.

Mots-clés : débit fluvial / eutrophisation / périphyton / macroinvertébrés / canal expérimental

\section{Introduction}

Stream ecosystems may respond to stressors through changes in their ecological structure and function (Gucker

\footnotetext{
*Corresponding author: susi.schneider@niva.no
}

et al., 2006; Hogsden and Harding, 2012). Traditionally, scientific studies have focused on the impact of one primary stressor on aquatic ecosystems (e.g. Biggs, 2000; Dangles and Guérold, 2000). In recent years, however, there have been attempts to understand how multiple stressors may simultaneously affect ecosystems, since this reflects more realistic conditions (e.g. Townsend et al., 2008; Ormerod et al., 2010). 
In Europe, pollution from agriculture and hydraulic engineering, i.e. the modification of the natural flow regime, are regarded as the main factors inhibiting the achievement of good ecological status of river basins (Menendez et al., 2005). The excessive use of fertilizer in agriculture may cause stream eutrophication, i.e. the accelerated growth of plants and algae caused by an increased nutrient loading (Schneider et al., 2016). The effects of eutrophication on the structure and function of stream ecosystems are relatively well understood, and commonly include an increase in periphyton biomass (Biggs, 2000), changes in species composition of macrophytes and benthic algae (Kelly and Whitton, 1998; Schneider and Melzer, 2003), or a decline in macrophyte species richness (Sand-Jensen et al., 2000). The change in the rate of leaf litter breakdown with nutrient enrichment is not as clear; as it has been shown to both increase (e.g. Greenwood et al., 2007) and decrease (e.g. Lecerf et al., 2006). Macroinvertebrate species richness may be lowered if certain species tend to predominate in response to nutrient loading (Lecerf et al., 2006; Stendera et al., 2012), or increase, if higher nutrient levels allow for the establishment of a more complex ecosystem (e.g. the intermediate disturbance hypothesis as proposed by Connell (1978)).

The flow regime is often regarded to be the key abiotic variable in river ecosystems (Poff et al., 1997; Bunn and Arthington, 2002). River flow is, however, notoriously variable. This variability may be related to natural factors such as climate, geology and topography. Long-term climate change is - in the Northern Hemisphere - expected to lead to an increase in the frequency and intensity of heavy precipitation events, thus increasing the magnitude of high flows (Fowler and Kilsby, 2007; IPCC, 2013). Natural fluctuations in river flow are fundamentally important for the ecological integrity of lotic ecosystems (Poff et al., 1997; Naiman et al., 2008). The flow regime of many rivers has, however, been modified, e.g. by dampening or eliminating natural floods and droughts in order to meet human needs such as transport, water supply, flood control or hydropower (Dynesius and Nilsson, 1994; Gleick, 2003). Such an anthropogenic modification often leads to a more uniform flow regime, including reduced peak discharges (Graf, 2006). The consequences of natural variation and anthropogenic modifications in flow to riverine biota have been relatively well studied (Rolls et al., 2012; Schneider and Petrin, 2017), and both flow maxima and minima are important. For example, spates can decrease the abundance and diversity of macroinvertebrates (Scrimgeour et al., 1988), but macroinvertebrate assemblages and trait composition are also affected by droughts (Monk et al., 2008; Bonada et al., 2007).

While the separate effects of nutrients and a change in stream flow are relatively well understood, the combined effects have received less attention. Matthaei et al. (2010) used flume experiments to study the interacting effects of water abstraction (i.e. reduced flow) and nutrient addition. They commonly observed single stressor effects of nutrients and reduced flow on macroinvertebrates, benthic algal biomass and leaf litter degradation. Significant interactions, however, were comparatively rare, and were only observed for macroinvertebrates, not for benthic algae or leaf litter degradation. Elbrecht et al. (2016) did a similar study in Europe, and the results supported Matthaei et al. (2010). Also Lange et al.
(2014) studied the effect of farming intensity and water abstraction on macroinvertebrate communities in 43 stream sites. However, farming intensity not only affected nutrient concentrations, but also fine sediment levels on the stream bed, as well as temperature and light conditions. At the same time, water abstraction not only affected water flow, but also enhanced the accumulation of fine sediments and changed temperature. These covariations made it difficult to infer possibly causal relationships between macroinvertebrates and the combined effects of changes in nutrient levels and flow variation.

We used flume experiments in order to study the effects of a temporary increase in river flow, e.g. reflecting a heavy precipitation event, both as a single stressor and in combination with an increase in nutrient supply. This is important, because forecasted climate change may not only lead to an increase in the frequency of heavy precipitation events (Fowler and Kilsby, 2007; IPCC, 2013), but also increase nutrient exports from agricultural land (Ulén et al., 2007). We focused on analysing the responses of macroinvertebrates, benthic algae and leaf litter decomposition, because they are generally regarded as key components of stream ecosystems (Matthaei et al., 2010). We also compared species composition of macroinvertebrates and soft-bodied benthic algae between the flumes and the nearby stream from which the flumes were supplied with water, in order to understand how well the flumes represented the corresponding stream ecosystem. That comparison was important because small scale experiments have long been criticised for giving highly replicable, but spurious, answers (Schindler, 1998).

We hypothesized that (1) the flumes would contain fewer invertebrate and periphyton taxa than the nearby stream, because the flumes represent artificial and uniform habitats; (2) the flow event would decrease the biomass and diversity of benthic algae and invertebrates due to scouring, (3) nutrients would increase the biomass of benthic algae and decrease the rate of leaf litter breakdown (Robinson and Gessner, 2000), and (4) a flow event in the high nutrient treatment would reduce benthic algae more than in the low nutrient treatment, because nutrient enriched habitats should have an increased biomass of algae which generally are assumed to be more susceptible to flow (Biggs et al., 1998a).

\section{Material and methods}

\subsection{Study site}

The flumes were located at Sagelva $\left(63.135^{\circ} \mathrm{N}, 9.853^{\circ} \mathrm{E}\right)$, a stream near Trondheim, Norway, downstream from a small waterfall on a small stream island. The study site was located approximately $1 \mathrm{~km}$ downstream from a lake outlet. The catchment vegetation in the vicinity of the study site mainly comprised coniferous forest trees, but broad-leaf trees, Betula sp., Salix sp., and Alnus sp., also grew in the riparian zone. Human activities in the catchment mainly entailed forestry and agriculture. During the experiments, the water in Sagelva was circumneutral $(\mathrm{pH}=7.7-7.8)$. Total organic carbon ranged from 4.0 to $4.6 \mathrm{mg} \mathrm{Cl}^{-1}$, calcium from 13.4 to $13.9 \mathrm{mg}^{-1}$, total phosphorus from 2 to $7 \mu \mathrm{g} \mathrm{P}^{-1}$, total nitrogen from 235 to $370 \mu \mathrm{g} \mathrm{N}^{-1}$, and nitrate from 102 to $138 \mu \mathrm{g} \mathrm{N}^{-1}$, respectively (own unpublished data obtained from four 


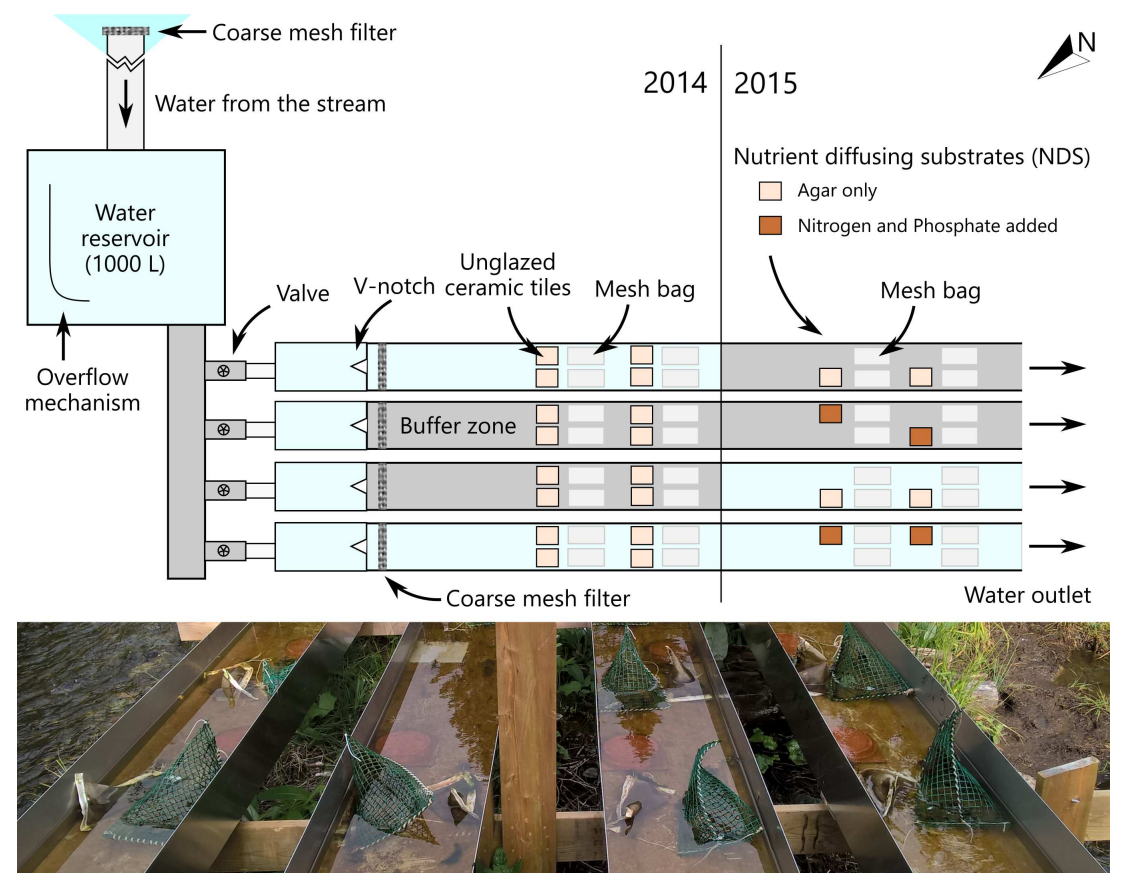

Fig. 1. Flume design and experimental setup in 2014 and 2015. In 2014, we used unglazed ceramic tiles and mesh bags. In 2015, we replaced the tiles with NDS. In each flume, there were two stations, one sampled prior to and one sampled after the flow event. Treatment, tiles and mesh bags were randomly distributed in both years and both experimental rounds.

samples taken during the study period; all measurements were performed in an accredited laboratory according to Norwegian standard procedures).

\subsection{Experimental flumes}

We constructed four metal flumes, each $4 \mathrm{~m}$ long and $32 \mathrm{~cm}$ wide, that were equipped with water delivery containers with large diameter taps allowing for separate manipulation of water flow in each flume (Fig. 1). Water was supplied to all flumes from a large delivery tank with an overflow mechanism, which was connected to a pool in Sagelva, guaranteeing a constant supply of water throughout the experimental period independent of the actual water level in the stream. To measure and help adjust discharge in each flume, we installed a V-notch and a tap in each flume, such that the water level behind the Vnotch corresponded to a defined discharge. Filtering devices were attached both at the tip of the supply pipe to the main delivery tank and below the V-notches to ensure that no coarse material could enter the flumes that might have clogged the experimental setup. The bottoms of the flumes included no mineral or organic substrate except for the experimental components. The flumes were exposed to sunlight and hence experienced the same light regime along their entire lengths.

The experiments were repeated twice in 2014, when we studied the effects of flow as a single stressor, and in 2015, when we studied the combined effects of flow and nutrient enrichment. The first experimental round was performed in July/August with the second round in August/September. During each experimental round, the flumes were operated for approximately two weeks following a pre-exposure period to allow for the development of a periphyton layer in the flumes (Tab. 1).
The base flow was in all experiments in both years sufficient to keep all experimental components in the flumes submerged. In order to study the effect of flow as a single stressor in 2014, we set two hydrological regimes. Base flow was set to $0.221 \mathrm{~s}^{-1}$ (corresponding to a flow velocity of $2.9 \mathrm{~cm} \mathrm{~s}^{-1}$ ) in all flumes and maintained throughout the experiment in two randomly selected flumes serving as controls. In the remaining two flumes, discharge was increased to $0.77 \mathrm{~s} \mathrm{~s}^{-1}$ (corresponding to a flow velocity of $6.9 \mathrm{~cm} \mathrm{~s}^{-1}$ ) for the duration of 3 days between the first and the second sampling, simulating a flow event that may for instance occur after rainfall. Thus, discharge during the event flow was $\approx 3.6$ fold larger than during base flow. The water depth was $2.3 \mathrm{~cm}$ at base flow and $3.5 \mathrm{~cm}$ during the event flow.

In order to study the combined effects of nutrients and flow in 2015, we manipulated nutrient levels in addition to the discharge levels. To allow for complete submersal of nutrient diffusing substrates (NDS), the water depth in the flume had to be increased by installing a threshold at the end of each flume. This increased the water depth at base flow to $3.5 \mathrm{~cm}$. Base flow was set to $0.07 \mathrm{l} \mathrm{s}^{-1}$ (corresponding to a flow velocity of $\left.1.3 \mathrm{~cm} \mathrm{~s}^{-1}\right)$. During the flow events water flow was $0.931 \mathrm{~s}^{-1}$ (corresponding to a flow velocity of $2.8 \mathrm{~cm} \mathrm{~s}^{-1}$ ). Water depth during the event flow was $4.8 \mathrm{~cm}$.

We installed drift nets with a mesh size of $250 \mu \mathrm{m}$ at the ends of the flumes to examine whether benthic macroinvertebrates may have drifted out of the flumes. Sampling was timed to begin with the onset of the flow event and lasted for one hour. All macroinvertebrates that were collected in the drift nets were preserved in $70 \%$ ethanol for later identification in the laboratory.

Last, we installed temperature loggers (HOBO Pendant Temperature/Light Data Logger, Onset Computer Corp.) in the 
K.A.E. Bækkelie et al.: Knowl. Manag. Aquat. Ecosyst. 2017, 418, 47

Table 1. Timing of sampling and duration of pre-exposure of mesh bags and tiles (2014) or nutrient diffusing substrates (2015). The start of the flow event is set as day 0 . Sampling 1 was performed before the onset of the flow event. MB = mesh bags, NDS = nutrient diffusing substrates.

\begin{tabular}{llllllll}
\hline Year & Round & Exposure of tiles/NDS in flumes & MB in stream & MB in flumes & Sampling 1 & Flow event & Sampling 2 \\
\hline 2014 & $1 \& 2$ & -13 & -6 to -3 & -3 & 0 & $0-3$ & 7 \\
2015 & $1^{*}$ & -3 & -6 to -3 & -3 & 0 & $0-3$ & 8 \\
2015 & $2^{* *}$ & -7 & -11 to -7 & -7 & 0 & $0-3$ & 7 \\
\hline
\end{tabular}

${ }^{*}$ Pre exposure time had to be reduced compared to 2014 due to a partial collapse in the supporting structure of the flumes.

${ }^{* *}$ Due to clogging of one of the valves, the experiment was restarted after one week, reducing the pre-exposure time of the NDS and extending the time the mesh bags were in the flumes prior to the flood.

stream and in one of the flumes during the experiments performed in 2015 , to test if water temperature would differ between the stream and the flumes and if this could explain potential differences in macroinvertebrate and algal assemblages between the stream and the flumes.

\subsection{Response parameters}

We used mesh bags filled with $1.5 \mathrm{~g}$ dried grey alder (Alnus incana) leaves to measure leaf litter decomposition (Benfield, 1996; Gessner and Chauvet, 2002). We used two mesh sizes, $0.5 \mu \mathrm{m}$ (=excluding benthic macroinvertebrates) and $1.2 \mathrm{~cm}$ (=allowing macroinvertebrates access to the leaf litter). After sampling, the mesh bags were stored at $-20^{\circ} \mathrm{C}$ prior to further processing. In the laboratory, grey alder leaf fragments were separated from mineral and other organic particles, and all macroinvertebrates were stored in $70 \%$ ethanol. The grey alder leaf material was dried, weighed, ashed and the remaining ash re-weighed to determine the dry mass remaining at sampling (Benfield, 1996). We also accounted for leaching and handling losses (Benfield, 1996). From the data, we calculated leaf litter decomposition rates employing linear and exponential models (Benfield, 1996). The leaf litter decomposition rates were separately calculated for fine and coarse mesh bags; reflecting decomposition due to microbial activity, the combined action of microbes and benthic macroinvertebrates and physical abrasion, respectively.

All macroinvertebrates colonizing the coarse mesh bags were identified to the lowest possible taxonomic level, usually species or genus, but oligochaetes, Hydraenidae and the larvae of some dipteran families could not be classified any further. The primary identification keys were Wallace et al. (1990), Arnekleiv (1995), Edington and Hildrew (1995), and Nilsson (1997). From the taxon lists, we calculated the following structural and functional variables: total invertebrate density; taxon richness; the richness of Ephemeroptera, Plecoptera and Trichoptera; Shannon-Wiener diversity; the percentage of rheophile taxa; as well as the relative abundance of invertebrate individuals in the functional feeding groups of shredders (feeding on coarse particulate organic matter), gatherer/collectors (feeding on fine particulate organic matter), grazers/scrapers (feeding on periphyton), and predators, following ASTERICS 4.0.4 (2014) as they provide a link to ecological processes.

In order to test the effect of increased flow as single stressor on periphyton, we used unglazed ceramic tiles $(140 \times 158 \mathrm{~mm})$ as a substrate for periphyton growth. In order to test the interacting effects of flow increase and nutrients, we used NDS. The NDS were constructed from inverted clay flowerpot saucers (outside diameter $15.5 \mathrm{~cm}$, height $3 \mathrm{~cm}$, volume: $350 \mathrm{~cm}^{3}$ ) mounted on unglazed ceramic tiles with silicon (Biggs and Kilroy, 2000). The flowerpot saucers and the tiles were soaked in distilled water for 4 days and dried before the addition of a solution of agar (2\%) with added nitrogen $(0.5$ molar solution of sodium nitrate) and phosphorus ( 0.05 molar solution of trisodium orthophosphate) or plain agar (2\%) for treatment and controls, respectively. Each clay saucer absorbed $30 \mathrm{~cm}^{3}$ of the agar solution in its pores, hence, in total $380 \mathrm{~cm}^{3}$ of solution were added to fill each clay saucer. After the gel reached room temperature, the clay saucers were mounted on ceramic tiles, and sealed with silicon.

On the tiles/NDS we measured total chlorophyll $a(C h l a)$ concentrations as a proxy of periphyton biomass, and also separately the $C h l a$ concentrations of cyanobacteria, green algae, and diatoms using a BenthoTorch, i.e. a Pulse Amplitude Modulated fluorimeter developed by BBE Moldaenke GmbH. In Swedish streams, the BenthoTorch has been shown to give similar readings for epilithic Chl $a$ as conventional methods (Kahlert and McKie, 2014). In the combined stressor experiments using NDS, the periphyton on the tiles was sampled after the BenthoTorch measurements, and preserved in $0.5 \%$ formalin. In the laboratory, algal cells were counted and measured, in order to quantify the biovolume of green algae, diatoms, and cyanobacteria, respectively, and to calculate the number of periphyton taxa that occurred in each sample.

\subsection{Experimental design}

Each flume was stocked with two pairs of coarse and fine mesh bags, and two tiles (2014) or two NDS (2015; Fig. 1). Tiles were installed in the flumes 13 days before the start of the flow event in order to allow for colonization with periphyton. For the same reason, NDS were installed 3-7 days before the start of the flow event. The position of the NDS's at the left or right-hand side in the flumes was randomized. The mesh bags were exposed for three days in the stream, maximum $20 \mathrm{~m}$ from the flumes, to allow colonization of invertebrates. After three days, the mesh bags were moved into the flumes. At each sampling occasion, one randomly selected pair of mesh bags and one tile or NDS was sampled. Sampling was performed twice, once before and once after the flow event (Tab. 1). Drift samples of invertebrates were collected in the beginning of the flow event. 


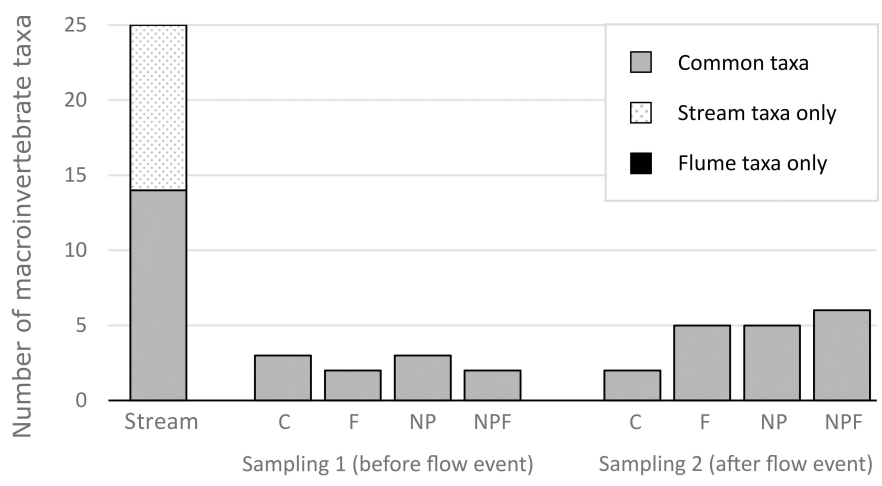

a)

September

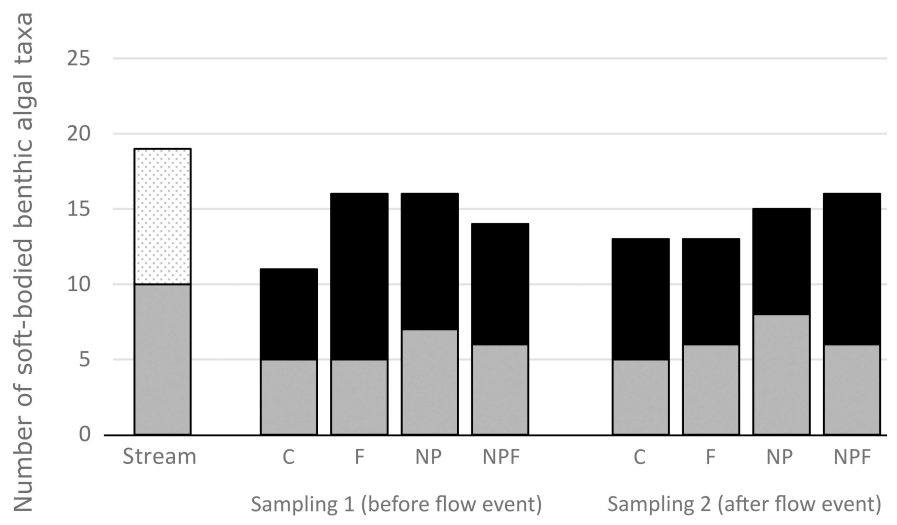

b)

July

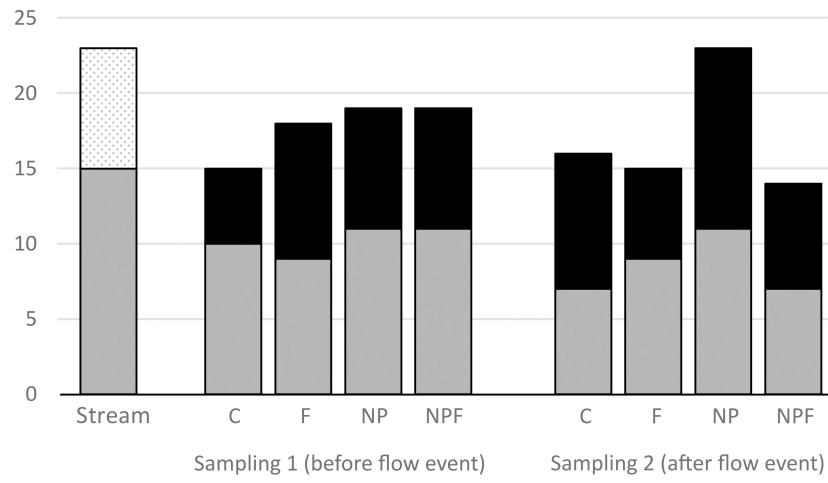

c)

September

Fig. 2. Number of benthic invertebrate (a) and soft-bodied benthic algae taxa ( $b=J u l y, c=$ September) that occurred in both stream and flumes (grey), in the stream only (white), and the flumes only (black). All data are from 2015. Treatments in the flumes are coded as $\mathrm{C}=$ control, $\mathrm{F}=$ flood, $\mathrm{NP}=$ nutrients, $\mathrm{NPF}=$ flow and nutrients. Note that sampling 1 occurred before the onset of the flow event.

\subsection{Sampling of stream periphyton and macroinvertebrates}

During each of the two experimental rounds performed in 2015, samples of soft-bodied benthic algae (=algae including cyanobacteria attached to the river bottom or in close contact on or within patches of attached aquatic plants, but excluding diatoms) were taken 5-10 m from where the flumes were located in Sagelva, according to European standard procedures (EN 15708:2009). All macroscopically visible benthic algae were collected and samples were stored separately in vials for species determination. In addition, microscopic algae were collected from ten cobbles/stones with diameters ranging between approximately 10 and $20 \mathrm{~cm}$. An area of about $8 \times 8 \mathrm{~cm}$ from the upper side of each cobble/stone was brushed with a toothbrush to transfer the algae into a beaker containing approximately $1 \mathrm{~L}$ of river water from which a subsample was taken. All samples were preserved with a few drops of formaldehyde to a final concentration of approximately $0.5 \%$. The preserved benthic algae samples were later examined under a microscope and all non-diatom algae identified to species, wherever possible. The primary identification keys used were Komarek and Anagnostidis (2007), Gutowski and Förster (2009), John et al. (2011) and Komarek (2013). For some genera of filamentous green algae whose vegetative forms cannot be determined to species level (e.g. Spirogyra Link or Mougeotia C. Agardh) categories based mainly on filament width were used (see Schneider and Lindstrøm (2009,
2011) for further details). In order to compare the species composition of benthic algae in the stream with the flumes, presence-absence data had to be used, because the semiquantitative sampling of taxa from a stream greatly differs from the quantitative sampling and enumeration that is possible on tiles/ NDS.

Macroinvertebrates from the Sagelva stream were collected in September 2015, 10-20 m from the flumes, from the same location where the mesh bags were pre-exposed prior to each experimental round. We performed qualitative sampling using kick-net (mesh size $500 \mu \mathrm{m})$ and three 1-min samples covering a total area of approximately $0.9 \mathrm{~m}^{2}$. The samples were processed in the laboratory, the macroinvertebrate community was determined to the lowest possible taxonomic level and recorded as present/absent.

\subsection{Data analysis}

We used the software package R 3.3.2 (R Core Team, 2016) including the packages vegan and lmerTest for data analysis (Oksanen et al., 2013; Kuznetsova et al., 2016). Data were log-transformed where necessary to improve normality and heteroscedasticity (visual inspection of histograms). We performed ANOVAs on linear mixed models using "experimental round" as random factor to analyze the individual and combined effects of an increase in nutrients and water flow on invertebrates, leaf litter degradation and periphyton algae. 
Table 2. Summary ( $p$-values) of ANOVAS comparing leaf decay and invertebrate parameters in mesh bags, as well as periphyton parameters on tiles between flow increase and control treatments. Significant effects $(p<0.05)$ of flow are marked in bold, $p$ values $<0.1$ are marked in italics.

\begin{tabular}{|c|c|c|}
\hline Dependent variable & Flow increase & Ranking \\
\hline \multicolumn{3}{|l|}{ Leaf litter decomposition rate } \\
\hline Coarse mesh bags (k) & 0.099 & Control $<$ flood \\
\hline Fine mesh bags $(\mathrm{k})$ & 0.204 & \\
\hline Coarse-fine (k) & 0.925 & \\
\hline \multicolumn{3}{|l|}{ Drift } \\
\hline Number of drifting individuals & 0.086 & Control $<$ flood \\
\hline \multicolumn{3}{|l|}{ Invertebrates in coarse mesh bags } \\
\hline Total invertebrate density & 0.162 & \\
\hline Taxon richness & 0.433 & \\
\hline EPT richness & 0.273 & \\
\hline Shannon-Wiener diversity & 0.286 & \\
\hline$\%$ Rheophile & 0.354 & \\
\hline Proportion of grazers/scrapers & 0.180 & \\
\hline Proportion of shredders & 0.678 & \\
\hline Proportion of gathering collectors & 0.548 & \\
\hline Proportion of predators & 0.295 & \\
\hline \multicolumn{3}{|l|}{ Periphyton } \\
\hline Total Chl a & 0.108 & \\
\hline Cyanobacteria & $0.026 *$ & Flood $<$ control \\
\hline Diatoms & 0.177 & \\
\hline Green algae & $0.009 *$ & Flood $<$ control \\
\hline
\end{tabular}

\section{Results}

\subsection{Differences between stream and flumes}

Water temperature in the Sagelva stream during the experiments in 2015 was $15 \pm 1^{\circ} \mathrm{C}\left(\min 12\right.$, $\max 18^{\circ} \mathrm{C}$; data not shown). In both experimental rounds, the water temperature in the flumes followed the same pattern as in the stream, but was slightly higher (paired $t$-test, exp. round $1:+0.20^{\circ} \mathrm{C}$ $(p<0.001)$, exp. round $\left.2:+0.04{ }^{\circ} \mathrm{C}(p<0.001)\right)$.

We found 25 taxa of benthic invertebrates in the Sagelva stream in September 2015 (Tab. S1). In contrast, there occurred on average $3.5 \pm 1.5$ macroinvertebrate taxa in a coarse mesh bag in the flumes in 2015. In total across both experiments and all treatments in 2015, 14 taxa were found in the mesh bags in the flumes. All of these taxa were also found in the September stream sample (Fig. 2, Tab. S1). Particularly Plecoptera, but also Ephemeroptera and Trichoptera were more species rich in the stream than in the flumes (Tab. S1). The most abundant taxa in the flumes were chironomids, the mayflies Baetis rhodani (Pictet, 1843) and Ephemerella ignita (Poda, 1761) and the wandering snail Radix balthica (Linnaeus, 1758) (Tab. S1). Generally, the number of individuals in the flumes was higher in July than in September (Tab. S1). The taxa that were only present in the stream included the mayfly Heptagenia sulphurea (Müller, 1776), the stoneflies Isoperla grammatica (Poda, 1761), Dinocras
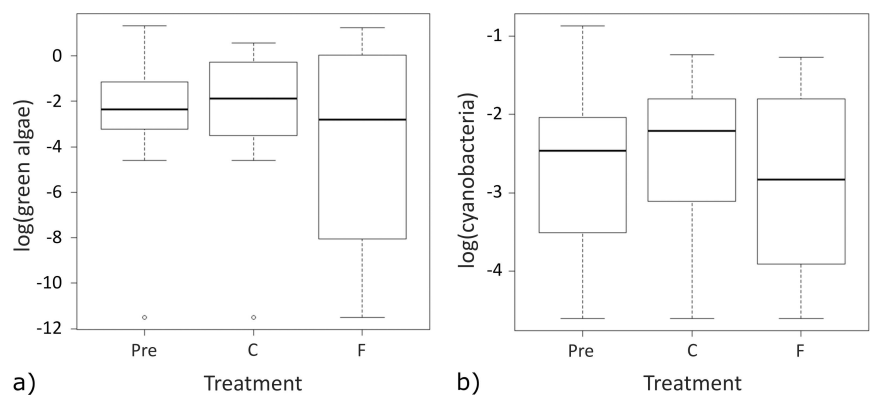

Fig. 3. Biomass of (a) green algae and (b) cyanobacteria (in $\mu \mathrm{g} \mathrm{Chl} \mathrm{a}$ $\mathrm{cm}^{-2}$ ) before the flow event (=day 0 of the experiment; indicated as "Pre"), and after the flood event (day 7 of the experiment) in control (C) and flow treatments (F). The box displays the first and third quartile, the band inside the box represents the median; the whiskers denote minimum and maximum; data more than 1.5 interquartile range below the first or above the third quartile, were treated as outliers (o).

cephalotes (Curtis, 1827), Perlodidae and Protonemura meyeri (Pictet, 1841), the caddisflies Hydropsyche sp. and Hydroptila sp., the riffle beetle Elmis aenea (Müller, 1806) and the dagger fly Empididae.

For soft-bodied benthic algae, generally more taxa occurred in September 2015 than in July, and fewer taxa in the flumes than in the stream (flumes: $16 \pm 3$ taxa; stream: $21 \pm 2$ taxa; Fig. 2). Across both experiments and samplings, $9 \pm 3$ taxa were shared between flumes and stream, $9 \pm 1$ taxa occurred only in the stream, and $8 \pm 2$ taxa occurred only in the flumes (Fig. 2). Among the most common taxa that occurred both in the stream and the flumes were Closterium sp., Cosmarium sp., narrow Mougeotia filaments, and Ulothrix sp. (Tab. S2 in the Supplementary Material). The most common taxa that occurred exclusively in the stream were epiphytic taxa like Chamaesiphon rostafinskii (Hansgirg, 1887), broad Oedogonium filaments, and the red algae Audouinella chalybaea ((Roth, 1806) Bory, 1823) and Batrachospermum sp. The most common taxa that occurred in the flumes only were small coccoid taxa like Aphanocapsa sp., Chroococcus sp. or Euastrum sp.

\subsection{Flow increase as single stressor}

The flow event decreased the biomass of cyanobacteria and green algae (Tab. 2; Fig. 3), but had no significant effect on any of the other response variables. However, leaf litter degradation in the coarse mesh bags tended to be enhanced in the flow treatment, but that trend was insignificant. Also, the number of drifting individuals tended to be higher in the high flow treatment, but that trend was also insignificant (Tab. 2). Compared to pre-flood conditions, the biomass of cyanobacteria and green algae increased slightly in the control treatments, but decreased in the flow treatments (Fig. 3).

\subsection{Combined effects of flow increase and nutrient addition}

Before the onset of the flow treatment (day 0 of the experiment), no significant effects were observed between 
Table 3. Summary ( $p$-values) of ANOVAS comparing leaf decay and invertebrate parameters in mesh bag samples, as well as periphyton parameters, on nutrient diffusing substrates between nutrient and flow treatments; samples were taken 5 (round 1) and 4 (round 2) days after the cessation of the three days long flow event; significant effects $(p<0.05)$ are marked in bold, $p$-values $<0.1$ are marked in italics.

\begin{tabular}{|c|c|c|c|c|c|c|}
\hline Dependent variable & Flow increase & Ranking & Nutrients & Ranking & Flow x nutrients & Type of interaction \\
\hline \multicolumn{7}{|l|}{ Leaf litter decomposition rate } \\
\hline Coarse mesh bags $(\mathrm{k})$ & 0.062 & Control $<$ flood & 0.295 & & 0.175 & \\
\hline Fine mesh bags $(\mathrm{k})$ & 0.818 & & 0.034 & Control $<$ nutrients & 0.058 & \\
\hline Coarse-fine $(\mathrm{k})$ & 0.221 & & 0.580 & & 0.052 & \\
\hline \multicolumn{7}{|l|}{ Drift } \\
\hline Number of drifting individuals & 0.311 & & 0.006 & Control $<$ nutrients & 0.507 & \\
\hline \multicolumn{7}{|c|}{ Invertebrates in coarse mesh bags } \\
\hline Total invertebrate density & 0.094 & Control $<$ flood & 0.353 & & 0.774 & \\
\hline Taxon richness & 0.274 & & 0.778 & & 0.981 & \\
\hline EPT richness & 0.422 & & 0.880 & & 0.880 & \\
\hline Shannon-Wiener diversity & 0.361 & & 0.999 & & 0.896 & \\
\hline$\%$ rheophile & 0.955 & & 0.074 & Nutrients $<$ control & 0.264 & \\
\hline Proportion of grazers/scrapers & 0.981 & & 0.747 & & 0.973 & \\
\hline Proportion of shredders & 0.883 & & 0.027 & Nutrients $<$ control & 0.704 & \\
\hline Proportion of gathering collectors & 0.317 & & 0.264 & & 0.703 & \\
\hline Proportion of predators & 0.535 & & 0.044 & Control $<$ nutrients & 0.480 & \\
\hline \multicolumn{7}{|l|}{ Periphyton } \\
\hline Total Chl a & 0.002 & Control $<$ flood & $<\mathbf{0 . 0 0 1}$ & Control $<$ nutrients & 0.014 & Antagonistic \\
\hline Cyanobacteria (Chl a) & 0.076 & Control $<$ flood & 0.003 & Control $<$ nutrients & $<\mathbf{0 . 0 0 1}$ & Antagonistic \\
\hline Diatoms (Chl a) & 0.001 & Control $<$ flood & $<\mathbf{0 . 0 0 1}$ & Control $<$ nutrients & $<\mathbf{0 . 0 0 1}$ & Antagonistic \\
\hline Green algae (Chl a) & 0.093 & Control $<$ flood & $<\mathbf{0 . 0 0 1}$ & Control $<$ nutrients & 0.523 & \\
\hline Biovolume Cyanobacteria & 0.349 & & 0.083 & Control $<$ nutrients & 0.610 & \\
\hline Biovolume green algae & 0.562 & & 0.145 & & 0.540 & \\
\hline Biovolume diatoms & 0.658 & & 0.054 & Control $<$ nutrients & 0.116 & \\
\hline Total biovolume & 0.819 & & 0.114 & & 0.305 & \\
\hline Taxon richness & 0.384 & & 0.793 & & 0.740 & \\
\hline
\end{tabular}

nutrient and control treatments in any of the response variables. However, degradation of leaf litter by macroinvertebrates (coarse-fine mesh bags) and total invertebrate density were marginally higher in the nutrient treatments (Tab. S3 in the Supplementary Material).

In the samples taken after the flow event, nutrient addition increased the biomass of all algal groups and of total Chl a, increased the leaf litter degradation rate in the fine mesh bags, increased the number of drifting individuals and the relative amount of predators, but decreased the relative amount of shredders (Tab. 3). The flow event increased total Chl $a$, and specifically the biomass of diatoms (Tab. 3). No interactions between flow and nutrient levels occurred for invertebrate variables, but antagonistic interactions were observed for cyanobacteria, diatoms and total Chl $a$ (Tab. 3; Fig. 4).

\section{Discussion}

\subsection{Differences in invertebrate and periphyton composition between stream and flumes}

Our results support hypothesis 1 , which stated that there would be fewer taxa in the flumes than in the stream. This was true for macroinvertebrates and soft-bodied benthic algae, although the difference in species number was more pronounced for macroinvertebrates (Fig. 2). Also taxon identity differed between stream and flumes, but in this case the difference was more pronounced for soft-bodied benthic algae (Fig. 2). In the macroinvertebrate assemblages there occurred taxa which exclusively were found in the stream ("stream only"), but all taxa that were found in the flumes also occurred in the stream (we found no "flumes only" taxa). In contrast, the benthic algal assemblages contained "flumes only" as well as "stream only" taxa. Our flumes were constructed as through-flow (i.e. without recirculating water) with rapid water exchange being provided directly from the stream, through a comparatively small tank which was necessary to enable constant water supply to all flumes. For these reasons, major differences in water physico-chemistry between flumes and stream are highly unlikely to have occurred. We monitored water temperature, and although the difference between stream and flumes indeed was significant, the difference of just 0.2 and $0.04{ }^{\circ} \mathrm{C}$ is so small that it is unlikely to have caused the observed difference in macroinvertebrate and benthic algal assemblages between stream and flumes.

The red algae Audouinella sp. and Batrachospermum sp. were absent from the flumes, likely due to the short duration of the experiment which prohibited the successful establishment of these slowly growing taxa on the tiles/NDS. For similar reasons, small epiphytes such as Chamaesiphon sp. also were absent from the flumes, likely because their successful establishment obviously only can occur after suitable substrate algae have colonized the flumes. Obviously, colonization by 

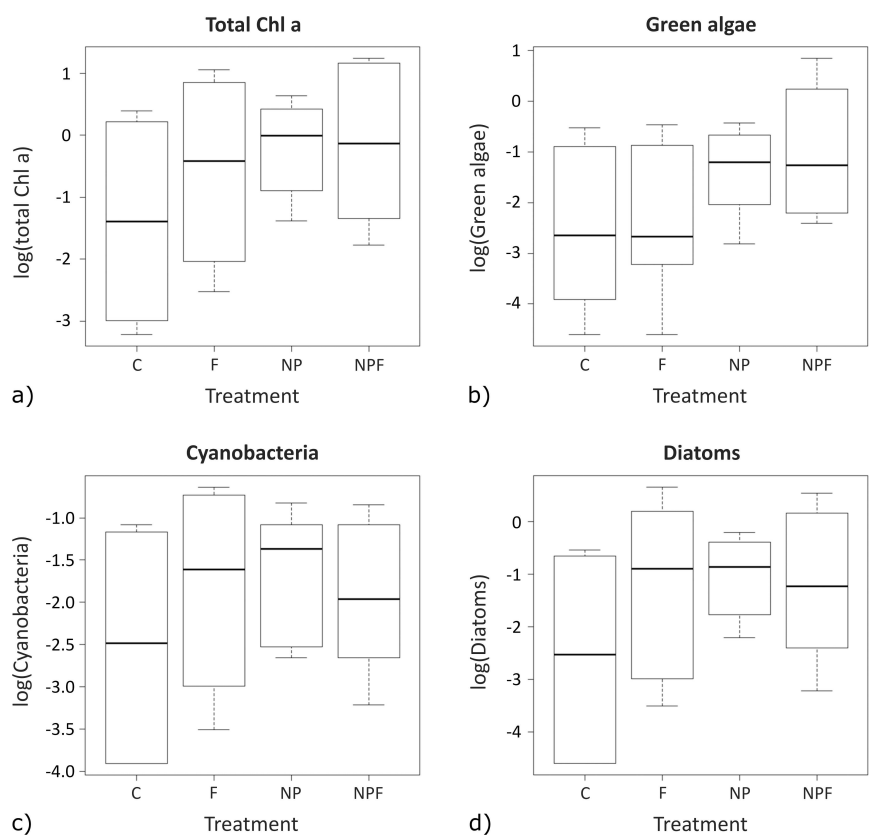

Fig. 4. (a) Total Chl a, as well as (b) biomass of green algae, (c) cyanobacteria and (d) diatoms (all in $\mu \mathrm{g} \mathrm{Chl} a \mathrm{~cm}^{-2}$ ) in control (C) and flow (F), nutrient (NP) and combined nutrient-flow (NPF) treatments. The box displays the first and third quartile, the band inside the box represents the median; the whiskers denote minimum and maximum; data more than 1.5 interquartile range below the first or above the third quartile, were treated as outliers (o).

epiphytic algae would have required more time than our experiment lasted. In contrast, small coccoid and fast growing algae preferably occurred in the flumes. This may be explained by the classical concept of C-S-R life history strategies (Grime, 1977), where small, rapidly growing "pioneer" or "ruderal" species succeed in disturbed (or new) habitats with moderate to high nutrient supply (Biggs et al., 1998b), a type of habitat which our previously uncolonized NDS likely represented.

With respect to macroinvertebrates, both the stream sample and the mesh bag assemblages from the flumes were dominated by generally abundant taxa, such as chironomids and the mayfly Baetis sp. However, particularly Plecoptera, but also Ephemeroptera and Trichoptera were more species rich in the stream than in the flumes, and many taxa that occurred in the stream were not found in the flumes. This may be due to several reasons: (i) insufficient numbers of a species were present in the stream during the time when the mesh bags were pre-exposed such that these species were rather unlikely to colonize the mesh bags; (ii) short duration of pre-exposure of the meshbags in the stream. Biasi et al. (2013) found that the colonization of leaf litter bags considerably changed within 22 days of exposure in a stream; our 3-4 days may therefore have been too short to capture the entire macroinvertebrate assemblage present in the stream. However, a longer preexposure in the stream was undesired because the leaf litter would have been degraded already before the bags were exposed in the flumes. (iii) Leaf litter bags may not be colonized by taxa which prefer hard substrates; the importance of substratum type on macroinvertebrate density and composition has for example been highlighted by Dumnicka et al. (2007). Many of these effects may possibly have been avoided by assisting the colonization of the flumes by adding a standard load of invertebrates obtained from the stream by kick-net sampling (as e.g. done by Matthaei et al., 2010).

Flume experiments are a common means to study the effect of stressors on stream ecosystems (e.g. Matthaei et al., 2010; Oldmeadow et al., 2010; Elbrecht et al., 2016), and conclusions with respect to structural and functional responses of stream ecosystems to stressors are frequently drawn from flume experiments (e.g. Ledger et al., 2011; Villeneuve et al., 2011; Ceola et al., 2013). However, biodiversity affects stream functioning through interspecific facilitation (Cardinale et al., 2002), and a higher biodiversity is generally assumed to stabilize ecosystem functions in response to disturbances and variation in abiotic conditions (Hooper et al., 2005). However, despite their widespread use in aquatic environments, few publications using flume experiments report the natural diversity of the analyzed organism groups in the nearby lotic ecosystem, and compared it with the diversity in the experimental flumes (but see Ledger et al., 2009). Although we do admit that the number of macroinvertebrate taxa in our flumes may have been enhanced, for example by adding standard loads from kick-net sampling in the Sagelva stream, our experimental design generally is similar to other flume experiments (e.g. Villeneuve et al., 2011; Cañedo-Argüelles et al., 2014). We therefore believe that diversity in experimental flumes maybe generally lower than in natural stream ecosystems, such as was the case in our experiments. Also Ledger et al. (2009) reported less taxa in the flumes than in the stream. This should mean that many flume experiments may lack "ecological realism" (Ledger et al., 2009). Experiments are necessary in order to deduce causal relationships, since these cannot be inferred from correlative field data. However, we agree with Schindler (1998) that small scale experiments may give highly replicable, but spurious, answers. It is therefore necessary to combine causal evidence from experiments with correlative evidence from field data. Only if both agree with each other, results from flume experiments may be assumed to be applicable in the "real world" with some confidence.

\subsection{Effects of flow increase and nutrients on leaf litter degradation, invertebrates and periphyton}

Hypothesis 2, which stated that the flow event would decrease benthic algae and macroinvertebrate biomass and diversity, was accepted for periphyton but rejected for macroinvertebrates. Drift of macroinvertebrates increased at the beginning of the flow event, although this effect only was marginally significant (Tab. 2). This meets expectations, because drift is a common response of macroinvertebrates to increased flow (Robinson et al., 2004). An increase of flow from 2.9 to $6.9 \mathrm{~cm} \mathrm{~s}^{-1}$ in the 2014 experiments decreased the biomass of cyanobacteria and green algae, but had no effect on any of the invertebrate response variables. This was not surprising, because macroinvertebrates and algae were collected from a stream next to our flumes. Although we do not have data on flow velocity from this stream, our flumes were constructed to have a similar flow velocity as the stream (based on visual inspection). The climate in Norway is 
notoriously variable, and frequent changes in stream discharge are common (www.nve.no). More serious spates in the stream Sagelva most probably comprise flow velocities well above $7 \mathrm{~cm} \mathrm{~s}^{-1}$, i.e. faster than what was possible to achieve in our experiments. It is reasonable to assume that most of the macroinvertebrate species we collected in the stream were adjusted to variations in flow velocity, and reacted by smallscale movements, e.g. alteration of body posture, to the increased flow velocity (Lancaster, 1999). The decrease in the biomass of benthic algae may be due to abrasion or scouring (Francoeur and Biggs, 2006). Overall, our experiments showed that an increase in flow velocity from 2.9 to $6.9 \mathrm{~cm} \mathrm{~s}^{-1}$ may lead to removal of some algae, drift of some invertebrates, but most macroinvertebrates will be able to cope with the increased flow by, for example, adjustments of body posture. It is, however, likely, that these effects in "real" stream ecosystems will not be long-lasting, because recolonization will commonly be fast (Schneider and Petrin, 2017).

An increase of flow from 1.3 to $2.8 \mathrm{~cm} \mathrm{~s}^{-1}$ in the 2015 experiments lead to an increase in the biomass of diatoms and total Chl $a$, but affected no other response variables (Tab. 3). This seems at first glance, contradictory to the results obtained in the 2014 experiments, where we observed a decrease in the biomass of cyanobacteria and green algae when flow was increased from 2.9 to $6.9 \mathrm{~cm} \mathrm{~s}^{-1}$. It is, however, a well-known phenomenon that mucilaginous algae, such as diatoms, may increase with flow velocity due to increased rates of nutrient transfer into the assemblages, while filamentous forms, such as green algae decrease due to scouring (Biggs et al., 1998a). In general, our results indicate an increase in flow velocity in the "lower" range may lead to an increased algal biomass, but that a further increase of flow velocity may lead to a decrease of algal biomass. This matches well with field data from Norway (Schneider, 2015), showing that a flood event may decrease algal cover in a headwater stream (where flow velocities during floods may be high), but a higher August flow actually increased green algal cover in a lake outlet (where changes in flow velocities generally are more buffered than in headwater streams).

Hypothesis 3, which stated that nutrients would increase the biomass of benthic algae and decrease the rate of leaf litter breakdown, was accepted for benthic algae but rejected for leaf litter breakdown. Nutrients did not have an effect on any of the periphyton response variables at day 0 (Tab. 3), likely because sampling after only 3-7 days of exposure of the NDS was too early to show an effect. However, one week later the nutrient treatment was associated with an increased biomass of cyanobacteria, diatoms and green algae (Tab. 3). Increased benthic algal growth at enhanced nutrient supply is a wellknown phenomenon (Francoeur et al., 1999). We found an increased rate of microbial degradation (fine mesh bags) in the nutrient treatments (Tab. 3). This fits well with early studies that have shown a faster breakdown in nutrient-rich systems (Webster and Benfield, 1986) and with experimental addition of nutrients (Robinson and Gessner, 2000). This was generally attributed to an increased availability of nitrogen to microbiota (Webster and Benfield, 1986). Also our study system was relatively poor in nitrogen (total nitrogen $235-370 \mu \mathrm{g} \mathrm{N}^{-1}$ ), such that a faster degradation of leaf litter in the nutrient enhanced treatment seems plausible.
We observed antagonistic interactions between nutrients and flow for total $C h l a$, diatoms and cyanobacteria, i.e. the combined effect of flow and nutrients was less than the sum of both individual effects (Piggott et al., 2015). As a single stressor, nutrients may lead to an increase in the biomass of benthic algae, and the same is true for an increased flow velocity in the range from 1.3 to 2.8 due to an improved transfer of nutrients into algal patches (see above). However, an increased biomass also is more susceptible to scouring such that the combined effect of nutrients and a flow increase is less than the sum of both individual effects. Hypothesis 4, which stated that a flow event in the high nutrient treatment would reduce benthic algae more than in the low nutrient treatment, was therefore partly accepted.

We observed fewer effects of increased flow on invertebrates than Elbrecht et al. (2016) or Matthaei et al. (2010) observed in their experiments testing reduced flows. We suggest that this may be explained because stream invertebrates in Norway may be adapted to frequent changes in stream flow caused by weather conditions. A long-lasting decrease in flow velocity, as tested by Elbrecht et al. (2016) and Matthaei et al. (2010) represents an entirely different stressor, entailing decreased oxygen concentrations, increased temperature and siltation. Experiments simulating an increase in flow are therefore not directly comparable with experiments simulating a decrease in flow.

\section{Supplementary Material}

Tables S1 to S3.

The Supplementary Material is available at http://www.kmaejournal.org/10.1051/kmae/2017041.

Acknowledgements. We thank Roger Meås and Svein Roar Åmot for help with the construction and installation of the experimental flumes, and we thank A ina Mærk A spaas and Thomas Ray Haaland for assistance during fieldwork. Terje Bongard kindly identified $p$ art of the b enthic macroinvertebrates, and Samuel Jack Poultney streamlined the English. The study was funded by the Research Council of Norway (ECOREG, 221398/E40) and by the EU 7th Framework Programme, Theme 6 (Environment including Climate Change) (MARS, Contract No.: 603378; http://www.marsproject.eu).

\section{References}

Arnekleiv JV. 1995. Bestemmelsesnøkkel til norske døgnfluelarver (Ephemeroptera larvae) [determination key to Norwegian ephemeroptera]. Stavanger: Norsk Entomologisk Forening, 47 p. (in Norwegian).

Benfield E. 1996. Leaf breakdown in stream ecosystems. Methods Stream Ecol 27: 579-589.

Biasi C, Tonin AM, Restello RM, Hepp LU. 2013. The colonisation of leaf litter by Chironomidae (Diptera): the influence of chemical quality and exposure duration in a subtropical stream. Limnologica 43: 427-433.

Biggs BJ. 2000. Eutrophication of streams and rivers: dissolved nutrient-chlorophyll relationships for benthic algae. $J \mathrm{~N} \mathrm{Am}$ Benthol Soc 19: 17-31. 
Biggs B, Kilroy C. 2000. Stream periphyton monitoring manual. Christchurch, New Zealand: National Institute of Water and Atmospheric Research.

Biggs BJ, Goring DG, Nikora VI. 1998a. Subsidy and stress responses of stream periphyton to gradients in water velocity as a function of community growth form. J Phycol 34: 598-607.

Biggs BJ, Stevenson RJ, Lowe RL. 1998b. A habitat matrix conceptual model for stream periphyton. Arch Hydrobiol 143: 2156.

Bonada N, Rieradevall M, Prat N. 2007. Macroinvertebrate community structure and biological traits related to flow permanence in a Mediterranean river network. Hydrobiologia 589: 91-106.

Bunn SE, Arthington AH. 2002. Basic principles and ecological consequences of altered flow regimes for aquatic biodiversity. Environ Manag 30: 492-507.

Cañedo-Argüelles M, Bundschuh M, Gutiérrez-Cánovas C, et al. 2014. Effects of repeated salt pulses on ecosystem structure and functions in a stream mesocosm. Sci Total Environ 476: 634-642.

Cardinale BJ, Palmer MA, Collins SL. 2002. Species diversity enhances ecosystem functioning through interspecific facilitation. Nature 415: 426-429.

Ceola S, Hödl I, Adlboller M, et al. 2013. Hydrologic variability affects invertebrate grazing on phototrophic biofilms in stream microcosms. PLoS ONE 8: e 60629.

Connell JH. 1978. Diversity in tropical rain forests and coral reefs. Science 199: 1302-1310.

Dangles OJ, Guérold FA. 2000. Structural and functional responses of benthic macroinvertebrates to acid precipitation in two forested headwater streams (Vosges Mountains, northeastern France). Hydrobiologia 418: 25-31.

Dumnicka E, Galas J, Koperski P. 2007. Benthic invertebrates in karst springs: does substratum or location define communities? Int Rev Hydrobiol 92: 452-464.

Dynesius M, Nilsson C. 1994. Fragmentation and flow regulation of river systemin the northern 3rd of the world. Science 266: 753-762.

Edington JM, Hildrew AG. 1995. A revised key to the caseless caddis larvae of the British Isles with notes on their ecology. Windermere: Freshwater Biol Assn, $134 \mathrm{p}$.

Elbrecht V, Beermann AJ, Goessler G, et al. 2016. Multiple-stressor effects on stream invertebrates: a mesocosm experiment manipulating nutrients, fine sediment and flow velocity. Freshw Biol 61: 362-375.

Fowler H, Kilsby C. 2007. Using regional climate model data to simulate historical and future river flows in northwest England. Clim Change 80: 337-367.

Francoeur SN, Biggs BJ. 2006. Short-term effects of elevated velocity and sediment abrasion on benthic algal communities. Advances in algal biology: a Commemoration of the work of Rex Lowe. Springer, 59-69.

Francoeur SN, Biggs BJ, Smith RA, Lowe RL. 1999. Nutrient limitation of algal biomass accrual in streams: seasonal patterns and a comparison of methods. JN Am Benthol Soc 18: 242-260.

Gessner MO, Chauvet E. 2002. A case for using litter breakdown to assess functional stream integrity. Ecol Appl 12: 498-510.

Gleick PH. 2003. Global freshwater resources: soft-path solutions for the 21st century. Science 302: 1524-1528.

Graf WL. 2006. Downstream hydrologic and geomorphic effects of large dams on American rivers. Geomorphology 79: 336-360.

Greenwood JL, Rosemond AD, Wallace JB, Cross WF, Weyers HS. 2007. Nutrients stimulate leaf breakdown rates and detritivore biomass: bottom-up effects via heterotrophic pathways. Oecologia 151: 637-649.
Grime JP. 1977. Evidence for the existence of three primary strategies in plants and its relevance to ecological and evolutionary theory. Am Nat 111: 1169-1194.

Gucker B, Brauns M, Pusch MT. 2006. Effects of wastewater treatment plant discharge on ecosystem structure and function of lowland streams. J N Am Benthol Soc 25: 313-329.

Gutowski A, Förster J. 2009. Benthische Algen ohne Diatomeen und Characeen [benthic algae except diatoms and charophyceae). Recklinghausen: LANUV-Arbeitsblatt 9, Landesamt für Natur, Umwelt und Verbraucherschutz Nordrhein-Westfalen, 490 p. (in German).

Hogsden KL, Harding JS. 2012. Consequences of acid mine drainage for the structure and function of benthic stream communities: a review. Freshw Sci 31: 108-120.

Hooper DU, Chapin F, Ewel J, et al. 2005. Effects of biodiversity on ecosystem functioning: a consensus of current knowledge. Ecol Monogr 75: 3-35.

IPCC. 2013. Summary for policymakers. In Stocker TF, Qin D, Plattner GK, et al., eds. Climate change 2013: the physical science basis. Contribution of working group I to the fifth assessment report of the Intergovernmental Panel on Climate Change. Cambridge, United Kingdom and New York, NY, USA: Cambridge University Press.

John DM, Whitton BA, Brook AJ, eds. 2011. The freshwater algal flora of the British Isles. London: Cambridge University Press, 702 p.

Kahlert M, McKie BG. 2014. Comparing new and conventional methods to estimate benthic algal biomass and composition in freshwaters. Environ Sci: Process Imp 16: 2627-2634.

Kelly MG, Whitton BA. 1998. Biological monitoring of eutrophication in rivers. Hydrobiologia 384: 55-67.

Komarek J. 2013. Cyanoprokaryota. In Büdel G, Gärtner G, Krienitz L, Schagerl M, eds.Süßwasserflora von Mitteleuropa, Bd. 19/3. Heidelberg: Spektrum Verlag, 1138 p.

Komarek J, Anagnostidis K. 2007. Cyanoprokaryota. In Büdel G, Gärtner G, Krienitz L, Schagerl M, eds.Süßwasserflora von Mitteleuropa, Bd. 19/1 and 19/2. Heidelberg: Spektrum Verlag, $1307 \mathrm{p}$.

Kuznetsova A, Bruun Brockhoff P, Haubo Bojesen Christensen P. 2016. lmerTest: tests in linear mixed effects models. $R$ package version 2: 0-33. https://cran.r-project.org/package=lmerTest.

Lancaster J. 1999. Small-scale movements of lotic macroinvertebrates with variations in flow. Freshw Biol 41: 605-619.

Lange K, Townsend CR, Matthaei CD. 2014. Can biological traits of stream invertebrates help disentangle the effects of multiple stressors in an agricultural catchment? Freshw Biol 59: 2431-2446.

Lecerf A, Usseglio-Polatera P, Charcosset JY, Lambrigot D, Bracht B, Chauvet E. 2006. Assessment of functional integrity of eutrophic streams using litter breakdown and benthic macroinvertebrates. Arch Hydrobiol 165: 105-126.

Ledger M, Harris R, Armitage P, Milner A. 2009. Realism of model ecosystems: an evaluation of physicochemistry and macroinvertebrate assemblages in artificial streams. Hydrobiologia 617: 91-99.

Ledger ME, Edwards FK, Brown LE, Milner AM, Woodward G. 2011. Impact of simulated drought on ecosystem biomass production: an experimental test in stream mesocosms. Global Change Biol 17: 2288-2297.

Matthaei CD, Piggott JJ, Townsend CR. 2010. Multiple stressors in agricultural streams: interactions among sediment addition, nutrient enrichment and water abstraction. J Appl Ecol 47: 639-649.

Menendez M, de Rooy M, Broseliske G, Mol S. 2005. Key issues and research needs under the water framework directive - final document, comprising phase 1 and phase 2, December 2005, Issue date: 26/01/2006. http://kalme.daba.lv/faili/LVAF_projekta_mater iali/WFD Key Issues and Research Needs - Final Version December 2005. pdf. 
Monk WA, Wood PJ, Hannah DM, Wilson DA. 2008. Macroinvertebrate community response to inter-annual and regional river flow regime dynamics. River Res Appl 24: 988-1001.

Naiman RJ, Latterell JJ, Pettit NE, Olden JD. 2008. Flow variability and the biophysical vitality of river systems. $C R$ Geosci 340: 629-643.

Nilsson A, ed. 1997. Aquatic insects of North Europe: a taxonomic handbook. Vester Skerninge: Apollo Books $440 \mathrm{p}$.

Oksanen J, Blanchet FG, Kindt R, et al. 2013. Package 'vegan'. Community ecology package, version 2.

Oldmeadow DF, Lancaster J, Rice SP. 2010. Drift and settlement of stream insects in a complex hydraulic environment. Freshw Biol 55: 1020-1035.

Ormerod S, Dobson M, Hildrew A, Townsend C. 2010. Multiple stressors in freshwater ecosystems. Freshw Biol 55: 1-4.

Piggott JJ, Townsend CR, Matthaei CD. 2015. Reconceptualizing synergism and antagonism among multiple stressors. Ecol Evol 5: $1538-1547$.

Poff NL, Allan JD, Bain MB, et al. 1997. The natural flow regime. BioScience 47: 769-784.

R Core Team. 2016. R: A language and environment for statistical computing. Vienna, Austria: R Foundation for Statistical Computing. https://www.r-project.org/.

Robinson CT, Gessner MO. 2000. Nutrient addition accelerates leaf breakdown in an alpine springbrook. Oecologia 122: 258-263.

Robinson CT, Aebischer S, Uehlinger U. 2004. Immediate and habitat-specific responses of macroinvertebrates to sequential, experimental floods. $J N$ Am Benthol Soc 23: 853-867.

Rolls RJ, Leigh C, Sheldon F. 2012. Mechanistic effects of low-flow hydrology on riverine ecosystems: ecological principles and consequences of alteration. Freshw Sci 31: 1163-1186.

Sand-Jensen K, Riis T, Vestergaard O, Larsen SE. 2000. Macrophyte decline in Danish lakes and streams over the past 100 years. J Ecol 88: $1030-1040$.

Schindler DW. 1998. Whole-ecosystem experiments: replication versus realism: the need for ecosystem-scale experiments. Ecosystems 1: 323-334.

Schneider SC. 2015. Greener rivers in a changing climate? Effects of climate and hydrological regime on benthic algal assemblages in pristine streams. Limnologica 55: 21-32.
Schneider S, Lindstrøm EA. 2009. Bioindication in Norwegian rivers using non-diatomaceous benthic algae: the acidification index periphyton (AIP). Ecol Ind 9: 1206-1211.

Schneider SC, Lindstrøm EA. 2011. The periphyton index of trophic status PIT: a new eutrophication metric based on non-diatomaceous benthic algae in Nordic rivers. Hydrobiologia 665: 143-155.

Schneider S, Melzer A. 2003. The trophic index of Macrophytes (TIM): a new tool for indicating the trophic state of running waters. Int Rev Hydrobiol 88: 49-67.

Schneider SC, Petrin Z. 2017. Effects of flow regime on benthic algae and macroinvertebrates: a comparison between regulated and unregulated rivers. Sci Total Environ 579: 1059-1072.

Schneider SC, Hilt S, Vermaat JE, Kelly M. 2016. The "forgotten" ecology behind ecological status evaluation: re-assessing the roles of aquatic plants and benthic algae in ecosystem functioning. Progress in Botany, Vol. 78. Heidelberg: Springer, pp. 285-304.

Scrimgeour GJ, Davidson RJ, Davidson JM. 1988. Recovery of benthic macroinvertebrate and epilithic communities following a large flood, in an unstable, braided, New Zealand river. $N Z J$ Mar Freshw Res 22: 337-344.

Stendera S, Adrian R, Bonada N, et al. 2012. Drivers and stressors of freshwater biodiversity patterns across different ecosystems and scales: a review. Hydrobiologia 696: 1-8.

Townsend CR, Uhlmann SS, Matthaei CD. 2008. Individual and combined responses of stream ecosystems to multiple stressors. $J$ Appl Ecol 45: 1810-1819.

Ulén B, Bechmann M, Fölster J, Jarvie H, Tunney H. 2007. Agriculture as a phosphorus source for eutrophication in the northwest European countries, Norway, Sweden, United Kingdom and Ireland: a review. Soil Use Manag 23: 5-15.

Villeneuve A, Montuelle B, Bouchez A. 2011. Effects of flow regime and pesticides on periphytic communities: evolution and role of biodiversity. Aquat Toxicol 102: 123-133.

Wallace ID, Wallace B, Philipson GN. 1990. A key to the case-bearing caddis larvae of Britain and Ireland (No. 51). Ambleside: Freshwater Biol Assn, 259 p.

Webster JR, Benfield EF. 1986. Vascular plant breakdown in freshwater ecosystems. Annu Rev Ecol Syst 17: 567-594.

Cite this article as: Bækkelie KAE, Schneider SC, Hagman CHC, Petrin Z. 2017. Effects of flow events and nutrient addition on stream periphyton and macroinvertebrates: an experimental study using flumes. Knowl. Manag. Aquat. Ecosyst., 418, 47. 